\title{
A VISIT TO THE FOUNDER
}

\section{Ronald Blythe}

(from Field Work: Selected Essays, Black Dog Books, 2007)

On a spring-like day in November 1959 John Cripps drove me from Burford to Idbury Manor to have lunch with J. W. Robertson Scott. I was fairly young, he was very old. 'I am ninety-four in the spring, born of Scots parents in a little Cumberland agricultural town, affectionately called by its inhabitants "the throstle's nest". He was slight and upright. The house was tall and bookish, that is both filled to the attics with volumes and also the kind of house which gets into novels. It smelled of waxed wood, apple-log smoke and bindings. Hyacinths bloomed in fat pots and a proper housekeeper appeared to lay the table. I think that I had only been to the Cotswolds once before and I remember finding a coolness which was quite unlike that of Suffolk. 'How will you get back to Burford?' I thought that John Cripps would fetch me but feeling that this might sound a rather luxurious answer to the austerities of Idbury Manor, I said I would walk.

'Good. I have always walked. I walked all over Japan when I was not much more than a boy. I was there for six years, avoiding cities, always exploring its rural districts. I edited a monthly called New East (Shin Toyo). It was half in English and half in Japanese and was published in Tokyo. And then I wrote a book called The Foundations of Japan'. He said it was like walking in the Middle Ages. With my head full of ferocious Shinto rites and film-makers' bandits, I said how brave he was. I saw this young Scot from Cumberland in terrible danger as he strode through this pre-Lieutenant Pinkerton landscape. But no. Everywhere he met with 
exquisite hospitality although hardly anyone in the villages had seen a European before. Should we have a walk now? Oh, yes, oh, certainly. The housekeeper fetched his coat. 'Lunch in an hour - no more!' she warned us, presumably knowing what his walks were. Out into the November sunshine. We took the lane which led from the Manor into Gloucestershire. It ran narrowly through bare fields. Robertson Scott stirred it up, made it lively, spoke to a roadman, showed me the Tree of Heaven which he had planted, and paused at a patch of burnt bank over which was scattered the calcined shells of many snails. 'Fire - a terrible death for a snail'. When we reached a much patched-up barn wall, he leaned against its warmth and we discussed the benefits of co-education. Thin old men turn into pencil drawings, their lines so fine, their skins so papery. Such white, shining hair. On the way back I noticed a swimming pool. He had enjoyed something I had written in The Countryman but could not recall what it was.

After lunch he showed me the room in which he had conceived The Countryman and, with his wife Elspet, edited it for many years. Again there was this predominance of wood. Although in the Cotswolds, the house had been built by a Scottish refugee who had fled his land after the Gowree conspiracy. It did not seem a house for a man in hiding being so conspicuously airy and open. Not a cosy house but one to be fit and busy in, and beautifully spotless. The bank told him that he was mad to launch a magazine but the manager sent a cheque for $£ 100$ with a note which said, 'If you are set on ruining yourself at least take a holiday with your wife first'. Sir Stafford Cripps and a Cotswold neighbour gave $£ 100$ a piece, a lot of money, as they say, then. Apart from this practical encouragement the rest of the cost was his own. Journalist colleagues from his days at the Pall Mall Gazette and the News Chronicle feared for his financial safety and actually came to Idbury to urge him not to go into publishing on his own. It was the 1920s, with farming in the doldrums and mass unemployment. But also, which his friends appear not to have observed, a kind of happiness-seeking flight into the countryside by any one with a good pair of boots or a bike. Though full of rural poverty and hardship, the villages 
and country towns also contained what was to be the last of a culture which had existed for centuries. There was in fact, when in April 1927, the first number of The Countryman appeared, a strong but ambivalent interest in rural Britain which was part love and part loathing, much of it born of the trenches.

This non-party, unsentimental, faintly Quakerish quarterly was, according to Robertson Scott's advisors, the wrong price, the wrong shape and came from very much the wrong address. Its peculiar green cover was made of something called 'Job Air Dried Cartridge', a paper invented for packing cartridges. By taking each fresh issue round London four times a year, the editor managed to pack it with advertising. This is a treasure-house for rural historians, from the Soil Association to Rising Damp, from Ladders for All Needs to Treneague camomile. I used to know the formidable old lady who advertised the latter. She lived in a ravine near Wadebridge, in a little white cottage with a Cornish slate floor, and with faggots blazing in a whitewashed fireplace, and she lived - on camomile. When, at twenty-five, the doctor told her that she would soon die, she got on the Cornish Riviera train, bought the cottage for $£ 50$ and grew a plant which became a legend. A poet friend and I would climb down to her deep paradise to have tea with her and the sparks would fly out at us and we would brush them from our clothes, and from her indifferent cat as we ate buttered toast. It was this year, 1959, that John Cripps had suggested a picture-cover for the magazine instead of a list of contents, and I had said that I would ask John Nash for some black and white 'seasons'. John Nash used to visit the Cotswolds as a child when his father, a lawyer, was on 'church business'. He and his brother Paul would draw and paint in the Gloucestershire meadows. John became great friends with the plant collector Clarence Elliott who created the now legendary Six Hills Nursery at Stevenage, and Robertson Scott persuaded them - he was a genius persuader - to collaborate on some memorable Countryman features.

Tea followed lunch in the failing November light. I told Robertson Scott that I was writing short stories and he told me 
that he had interviewed - H.M. Stanley. And that he had dined with a man who had dined with Coleridge, making me do arithmetic in my head, not from disbelief but as though to underline such a confession. I was beginning to wonder how I would get back to Burford, then to Oxford and then to Suffolk, although such a journey appeared petty compared with walking across Japan. Should I telephone John Cripps? Who would dare to ask? All around us were the framed oriental paintings of Robertson Scott's sister-in-law Elizabeth Keith, glinting in the shadows. There was a photograph of Bernard Shaw. Robertson Scott said that he and his contemporaries, W. T. Stead, Alfred Spender and H. W. Massingham had been trained in a tough journalists' world but he hoped that the result justified the effort. He was proud of The Countryman. It was a creation like none other on the bookstall he thought. He was, he said, a man in love with language. He had written me a letter on "how to deal with an elderly gentleman' and I should have made more notes, except that the ambience or atmosphere, or whatever one likes to call it, of the book-laden Manor caused a drift.

The talk turned to Little Easton in Essex where I sometimes stayed with Canon Barnett the far-from Socialist rector who once, when I had returned from a walk to the village asked, 'What is it like down there?' 'What is Little Easton like these days?' asked Robertson Scott, who had lived there when Lady Warwick had gathered all the likeminds she could find to be her tenants, H. G. Wells, Gustav Holst, S. L. Bensusan, A. E. Coppard, Solomon the pianist and Conrad Noel and many others. He listened to the sad tale. The Lodge was no more. Its coroneted gates were doubly locked with rust and spear-grass, the park where Mr Britling saw the Great War through was littered with the remains of a P.O.W. camp.

'But what a tremendous thing to have done, to have found the Gowrie conspirator's house and then founded a famous magazine!'

'I get tired,' he said.

The tiredness of old age is unlike all other tiredness. To be ninety-four next April makes one sleepy. John Cripps drives 
up and tells me, 'Plenty of time, plenty of time!' Whilst he is having tea I return to the shelves on which there is a complete run of The Countryman, really to see again some of the early photographs of which I am so fond, and here is a picture of 'Clarence Elliott at Home in the Cotswolds' squatting by a raised bed. Like Robertson Scott he had turned 'his baby' Six Hills Nursery' - over to a successor having arrived at what he describes as 'the rest of the road'. In the spring 1948 Countryman he writes, 'Plants and travel have kept me busy and poor enough to be uncommonly happy ... I have now found what I wanted in the Cotswolds.' This distant day hurried back to me as we left the Cheltenham Literature Festival last autumn via a series of by-roads in order to make the most of a rare journey to Gloucestershire. To substantiate its haziness I discovered a letter from Robertson Scott which said, 'First money earned in journalism, 4s. 9d. from C. P. Scott (no relation). Below it he has scribbled some praise from The Times. 'Without The Countryman there is a narrowing of knowledge, interest and power'. And this must be true. The photography in the early numbers is a revelation, some of it the kind of thing which now one only sees in a Fay Godwin exhibition, and the articles, although noncampaigning, lack complaisancy. Robertson Scott was a late Victorian and, looking back, I can see that something of the rigorousness of those early days was seeded into his 1927 venture. How pleased he would be to know that it remains a lively one in 2002. 